\title{
Evaluation of anticonvulsant activity of ethanolic leaves extract of Desmodium triflorum in mice
}

\author{
Girish Gowda, ${ }^{, 1}$ Vaibhav Bhosle, ${ }^{2}$ John Wilking Einstein, ${ }^{2}$ \\ Kuntal Das, ${ }^{2}$ Benson Mathai ${ }^{2}$ \\ ${ }^{1}$ Department of Pharmacognosy and Phytochemistry, St. John's Pharmacy College, \\ Bangalore, Karnataka, India, \\ ${ }^{2}$ Department of Pharmacology and Toxicology, St. John's Pharmacy College, \\ Bangalore, Karnataka, India.
}

\begin{abstract}
The present investigation was aimed to study an anticonvulsant activity of ethanolic extract of Desmodium triflorum (L.) DC., Fabaceae, in mice. Animal models of epilepsy namely the pentylenetetrazole (PTZ), isoniazid or isonicotinic hydrazide (INH) and maximal electroshock induced convulsion (MES) were used to evaluate the anticonvulsant effects of the extracts. The biochemical estimation was done by measuring the lipid peroxidation and reduced glutathione (GSH). In the PTZ induced convulsion, ethanolic extract of $D$. triflorum (EEDT) $400 \mathrm{mg} / \mathrm{kg}$ significant delayed the onset of convulsion, reduced the duration of convulsion and reduced mortality. Similarly a dose of $800 \mathrm{mg} / \mathrm{kg}$ of EDDT significantly delayed the onset of convulsion, reduced the duration of convulsion and showed $33.33 \%$ protection in mice against INH induced convulsion. Further no mortality was found. Both the doses reduced hind limb tonic extension (HLTE) phase of MES induced convulsion in mice. The pretreated EEDT showed significant inhibition of lipid peroxidation and increases the reduced glutathione level in mice brain tissue. The results revealed that $D$. triflorum possesses a significant dose dependent anticonvulsant activity.
\end{abstract}

Revista Brasileira de Farmacognosia Brazilian Journal of Pharmacognosy 22(3): 649-656, May/Jun. 2012

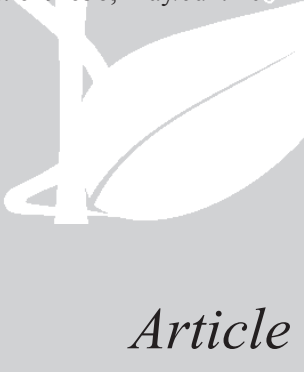

Article

Received 9 Sep 2011

Accepted 3 Nov 2011

Available online 31 Jan 2012

Keywords: anticonvulsant activity Desmodium triflorum isoniazid maximal electroshock pentylenetetrazole

ISSN 0102-695X http://dx.doi.org/10.1590/S0102695X2012005000019

\section{Introduction}

Epilepsy is a chronic brain disorder characterized by recurrent derangement of the nervous system due to sudden excessive disorderly discharge from the cerebral neurons (Maiha et al., 2009). It is the second most common neurological disorder with an annual incidence of 50 cases $/ 100000$ per year. Overall it accounts for $1 \%$ of the world's burden of diseases, and the prevalence rate is reported at $2 \%$ (Vyawahare et al., 2007). Seizures are controlled in nearly $70 \%$ of patients with epilepsy, mostly through drugs effect on membrane ion channels or on gamma amino butyric acidergic (GABA) or glutamatergic transmission (Marjan et al., 2009). World Health Organization (WHO) estimated that approximately $80 \%$ people with epilepsy live in developing countries and most of them do not get adequate medical treatment (Reddy, 2005). All the currently available antiepileptic drugs are synthetic molecules (Hema et al., 2009). In many patients, the presently available antiepileptic drugs (AED) such as phenobarbital, phenytoin, benzodiazepines, sodium valproate, carbamazepine, ethosuximide, trimethadione etc., are unable to control seizures efficiently. Furthermore, the dose-related neurotoxicity and other side effects associated with established AED limit their clinical use. The newer AED like oxcarbazepine, vigabatrin, lamotrigine, gabapentin, felbamate etc., represent a real progress in the treatment of no responders or refractory patients. However, the problem of adverse effects has also not been circumvented completely and approximately $30 \%$ of the patients continue to have seizures with current antiepileptic drugs therapy (Ezekiel et al., 2010). Hence, search should continue to develop newer, more effective, and safer neuroprotective agents for treatment of epilepsy. Medicinal plants used in traditional medicine for the treatment of epilepsy have been scientifically shown to posses promising anticonvulsant activities in animal models for screening for anticonvulsant activity (Wannang et al., 2008).

Herbal medicine is still the mainstay of about $75-80 \%$ of the world population, mainly in the developing countries, for primary health care because of better cultural acceptability, better compatibility with the human body and lesser side effects. However, the last few years have seen a major increase in their use in the developed world. Global estimates indicate 
that $80 \%$ of about 4 billion population cannot afford the products of the Western Pharmaceutical Industry and have to rely upon the use of traditional medicines which are mainly derived from plant material (Joy et al., 2001). Considering the great reliance on traditional medicinal plants for treatment of diseases and the potential for drug discovery; it becomes relevant to search for potent, effective and relatively safe plant medicines.

Of late, Desmodium triflorum (L.) DC., Fabaceae, is a perennial herb belonging to the family Papilionaceae (Kirtikar \& Basu, 1980). The plant is available in all tropical countries. It contains hypaphorine (major alkaloid), N,N-dimethyltryptophan betain and choline (Ghosal et al., 1971). D. triflorum leaves contains total alkaloid, $0.01-0.015 \%$ and rare diholosylflavone, 2-O-glucosylvitexin had been isolated from D. triflorum (Adinarayana \& Syamsundar, 1982). It also contains ursolic acid, vitexin, genistin, fucosterol (Yoganarasimhan, 1996). In traditional medicinal system, different parts of the plant have been mentioned to be useful in a variety of diseases. The leaves are used in diarrhoea, convulsions, antispasmodic, sympathomimetic, central nervous system stimulation, curare-mimetic activity and diuretic and as a galactagogue (Yoganarasimhan, 1996). The fresh leaves of the plant are applied to wounds and abscesses that are usually difficult to heal. The paste is sometimes applied to sores and itch. The fresh juice of the plant is often given to the children for coughs and asthma. The traditional use of the plant also recommends for use in dysentery and as a laxative (Adinarayana \& Syamsundar, 1982), high fever (Samvatsar, 2004) and cure bone-fracture (Prusti \& Behera, 2007). Different extracts of $D$. triflorum exhibit analgesic and antiinflammatory activities (Kawshik et al., 2005) and also possesses antioxidative and antiproliferative activities. (Mao et al., 2007; Lai et al., 2010). Recently antinociceptive activity of cold water extract of $D$. triflorum DC in rats (Daya et al., 2011) and antioxidant activities of phenolic components from various plants of Desmodium species were studied (Tsai et al., 2011) however, only limited data are available concerning the anticonvulsant activity of this plant species hence the present work was undertaken to evaluate the anticonvulsant activity of an ethanolic extract of $D$. triflorum leaves.

\section{Material and Methods}

\section{Plant material}

Desmodium triflorum (L.) DC., Fabaceae, was collected from Gandhi Krushi Vignana Kendra (GKVK) Bangalore. The plant was identified and authenticated by Dr. Siddamallayya, National Ayurvedic Dietetics Research Institute Bangalore. The voucher specimen is preserved in our laboratory for future reference.

\section{Preparation of extract}

The leaves of the plant species collected were dried under shade for a period of four weeks. The dried plant material was milled to a fine powder using the commercial laboratory blender. Dried powder (300 g) was extracted in a Soxhlet extractor with ethanol for about $8-9 \mathrm{~h}$ at $45{ }^{\circ} \mathrm{C}$. Extract was collected and dried using rotary flash evaporator at $40-45{ }^{\circ} \mathrm{C}$ and crude residue was collected. The yield was calculated as 30 g. The extract was stored in well closed glass container at $5{ }^{\circ} \mathrm{C}$ in refrigerator for further study.

\section{Preliminary phytochemical analysis}

The extracts obtained were subjected to various chemical tests to detect the chemical constituents present in them (Trease \& Evans, 1983; Khandelwal, 1996).

\section{Animals}

Healthy Swiss albino mice of either sex (18$20 \mathrm{~g})$ were procured from the Central Animal Facilities of the Drug Testing Laboratory (DTL), Bangalore. Animals were housed at our Institute's animal house facilities until they gained significant weight $(25 \pm 5$ g) suitable for the present investigation. The estrous cycle in female mice was observed normal. They were housed in hygienic cages (polypropylene cage) and maintained under standard laboratory conditions for one week before the experiments started and were kept in groups of six per cage at controlled temperature $(22 \pm 20 \mathrm{C})$ with $12 \mathrm{~h} \mathrm{light/dark}$ cycle and humidity $(50 \%)$. They received standard diet and water ad libitum. The animals were maintained in accordance with CPCSEA (Committee for the Purpose of Control and Supervision of Experimental Animals) guidelines for the care and use of laboratory animals. Approval for the experiment was obtained from the Institutional Animal Ethics Committee (IAEC), St. John's Pharmacy College, Vijayanagar, Bangalore, letter No. IJAHSM/ IAEC/2010-04.

\section{Acute toxicity study}

Acute toxicity study for the ethanolic and aqueous extract of $D$. triflorum was done according to the OECD guidelines No: 423 and low and high dose was selected for treatment. The ethanolic extract $(70.0 \%)$ of $D$. triflorum was administered orally in 
the escalating dosages, up to $2000 \mathrm{mg} / \mathrm{kg}$ to different groups of rats $(n=6$, in each). The animals were observed for behavioral and physiological variations initially continuously for $4 \mathrm{~h}$, followed by 4 th hourly for $12 \mathrm{~h}$ and there after once daily for fourteen days. If toxic signs or lethality is not observed, then $1 / 5^{\text {th }}, 1 / 10^{\text {th }}$ and $1 / 20^{\text {th }}$ part of the limit test dose were considered as test doses for the present investigation.

\section{Anticonvulsant screening method}

Pentylenetetrazole (PTZ) induced convulsion

Animals were divided into IV groups, $(n=6$ mice of either sex in one group). Group I received respective vehicles; group II was allotted for standard drug (diazepam $5 \mathrm{mg} / \mathrm{kg}$ ) and group III, and IV received EEDT at different dose levels. All treatment and standard groups were statistically compared with vehicle groups. Vehicles, extracts are administered by oral route and standard drugs were administered by intra-peritoneal (i.p.) route. Mice were administered extracts for seven days and on the experimental day, PTZ $65 \mathrm{mg} / \mathrm{kg}$ was injected intra-peritoneally to mice $45 \mathrm{~min}$ after vehicle or extracts and $30 \mathrm{~min}$ after the standard drug. Immediately after PTZ administration mice were observed for (1) onset of convulsions (elapsed time from PTZ injection until convulsion occurred), (2) duration of convulsion (number of mice showing convulsions) and (3) mortality for the duration of 30 minutes (Swinyard et al., 1952).

Isoniazid or isonicotinic hydrazide (INH)induced convulsion

Animals were divided into IV groups ( $\mathrm{n}=6$ mice of either sex in one group). Group I received respective vehicles, group II was allotted for standard drug (diazepam $10 \mathrm{mg} / \mathrm{kg}$ ). Group III and IV were received EEDT extracts at different dose levels. All treatment and standard groups were statistically compared with vehicle groups. Vehicles, extracts are administered by oral route and standard drugs were administered by subcutaneous (s.c.) route. Mice were administered extracts for seven days and on the experimental day, isonicotinic hydrazide (INH) $300 \mathrm{mg} / \mathrm{kg}$ was subcutaneous injected to mice $45 \mathrm{~min}$ after vehicle or extracts and $30 \mathrm{~min}$ after the standard drug. Immediately after isonicotinic hydrazide (INH) administration mice were observed for onset of convulsion, incidence of convulsion and death was recorded (Vogel \& Vogel, 2002).

convulsions
The electroshock was applied via ear-clip electrodes separately to each mouse. The stimulus duration was $0.2 \mathrm{~s}$ and the current frequency $45 \mathrm{~mA}$ $(60 \mathrm{~Hz})$. Six mice of either sex in one group with a weight of $25 \pm 5 \mathrm{~g}$, mice were administered extracts for seven days and on the experimental day, test was started $60 \mathrm{~min}$ after administration of extracts and 30 min after standard drug (phenytoin $25 \mathrm{mg} / \mathrm{kg}$ i.p.). The animals were observed for the occurrence of tonic hind limb extension and mortality for duration of $15 \mathrm{~min}$ (Swinyard et al., 1952). The EEDT was administered to Group III and IV where as group I and II received 2\% of Tween 80 and Phenytoin $25 \mathrm{mg} / \mathrm{kg}$ i.p., respectively.

\section{Biochemical estimation}

\section{Tissue preparation}

Three groups were used $(n=6)$. Group I animals (control) were administered $2 \%$ tween $80(2.0 \mathrm{~mL} / \mathrm{kg}$, oral $)$, Groups II and III animals were administered 400 and 800 $\mathrm{mg} / \mathrm{kg}$ of the EEDT orally. One hour after administration of the extract, PTZ $(65 \mathrm{mg} / \mathrm{kg})$ was injected i.p. to all the animals in Groups. On observing onset of convulsions, duration of seizure following the administration of PTZ, the animals (including control group) were sacrificed by decapitation and brain was removed, homogenized in $0.9 \% \mathrm{NaCl}$ by using Remi motor RQT-1.2.7A.

\section{Lipid peroxidation in brain}

Two milliliter of suspension medium was taken from $10 \%$ of tissue homogenate. To this, $2 \mathrm{~mL}$ of $30 \%$ of trichloroacetic acid was added, followed by $2 \mathrm{~mL}$ of $0.8 \%$ thiobarbituric acid (TBA) reagent. The tubes were covered with aluminum foil and kept in shaking water bath for half an hour at $80{ }^{\circ} \mathrm{C}$ after half an hour; the tubes were taken out and kept in ice cold water for half an hour. There were then centrifuged at $3000 \mathrm{x} g$ for $15 \mathrm{~min}$. The absorbance of the supernatant was read at $535 \mathrm{~nm}$ at room temperature against appropriate blank. Blank consist of $2 \mathrm{~mL}$ distilled water, $2 \mathrm{~mL}$ of $30 \%$ TCA and $2 \mathrm{~mL}$ of $0.8 \%$ TBA (Ohkawa et al., 1979). The content of malonaldehyde (MDA), expressed as $n$ moles formed per milligram of protein in the tissue, was calculated using the formula:

$$
\text { Concentration }=\mathrm{A} \times(\mathrm{V} / \mathrm{E}) \times \mathrm{P}
$$

Where, $\mathrm{A}$ is the volume of solution, $\mathrm{E}$ is extinction coefficient $\left(1.56 \times 10^{5} \mathrm{~m}^{-1} \mathrm{~cm}^{-1}\right)$ and $\mathrm{P}$ is the protein content of tissue calculated as milligram of protein per gram of tissue. 
Brain glutathione

To $2 \mathrm{~mL}$ of $10 \%$ of homogenate, which was prepared in sodium chloride solution, $2.5 \mathrm{~mL}$ of $0.02 \mathrm{M}$ EDTA was added and shaken vigorously. To $2 \mathrm{~mL}$ of this mixture $4 \mathrm{~mL}$ of cold distilled water and $1 \mathrm{~mL}$ of $50 \%$ trichloroacetic acid were added and shaken for $10 \mathrm{~min}$. Thereafter, the content were centrifuged at $3000 \times \mathrm{g}$ for 15 min following centrifugation, $2 \mathrm{~mL}$ of the supernatant was mixed with $0.4 \mathrm{M}$ tris buffer ( $\mathrm{pH} 8.9$ ). The whole solution was mixed well and $0.1 \mathrm{mLl}$ of $0.01 \mathrm{M}$ DTNB was added, the absorbance was read within 5 min of addition of DTNB at $412 \mathrm{~nm}$ against reagent blank with no homogenate. For blank reading, the homogenate was substituted by $2 \mathrm{~mL}$ of distilled water (Sedlak \& Lindsay, 1968). The amount of glutathione in tissue was expressed as $\mu \mathrm{mol} / \mathrm{g}$ of tissue.

$\mu \mathrm{mol} / \mathrm{mg}$ wet tissue: [A/13600] x dilution factor $\mathrm{x} 1000$.

\section{Statistical analysis}

The data obtained by the various parameters was statistically evaluated by one way analysis of variance (ANOVA) followed by Dunneet's Multiple Comparison Test by Graph Pad Prism software (GraphPad software Inc., Version 5.0.0). The mean values \pm SEM were calculated for each parameter. Level of significance was kept at $p<0.05$.

\section{Results}

\section{Preliminary phytochemical screening}

Phytochemical analysis of the ethanolic extract of $D$. triflorum (EEDT) revealed the presence of alkaloids, proteins, flavonoids, phytosterol, saponin and tannins. However, the tests show that they do not contain carbohydrate, glycoside and fixed oil and fats.

\section{Acute oral toxicity}

Acute oral toxicity studies revealed the non-toxic nature of the EEDT. Ethanolic extract and aqueous extracts of $D$. triflorum did not show any sign and symptoms of toxicity and mortality up to $2000 \mathrm{mg} /$ $\mathrm{kg}$ dose after fourteen days of study. This indicates that the extracts were found to be safe up to the dose levels studied. Since, all the animals survived at a dose of $2000 \mathrm{mg} / \mathrm{kg}$ body weight, the LD50 of the extract will be $>2000 \mathrm{mg} / \mathrm{kg}$ body weight. No major behavioral changes were observed during the period of study.

\section{Anti-convulsant activity}

Effect of extracts on pentylenetetrazoleinduced convulsion

Pentylenetetrazole $(65 \mathrm{mg} / \mathrm{kg}$, i.p. $)$ produced convulsion in all the animals used. All extracts groups compared with the control group. Mice pretreated with EEDT at the dose of $400 \mathrm{mg} / \mathrm{kg}$ p.o. showed significant delay the onset of convulsion $(p<0.01)$, significantly reduced the duration $(p<0.01)$ of pentylenetetrazole induced seizures in mice and reduced mortality to $16.67 \%$. Similarly a dose of $800 \mathrm{mg} / \mathrm{kg}$ p.o. of EEDT significantly delayed the onset of convulsion $(p<0.01)$, reduced the duration of convulsion $(p<0.01)$ and not found any mortality. The standard anti-epileptic drugs, Diazepam $(5 \mathrm{mg} / \mathrm{kg})$ blocked the clonic convulsions and mortality in mice against pentylenetetrazole induced convulsion (Table 1).

convulsion

Effect of extracts on Isoniazid-induced

Isoniazid (300 mg/kg, s.c.) produced tonicclonic seizures in all the animals used. The EEDT group was compared with control group. A dose of 400 $\mathrm{mg} / \mathrm{kg}$ p.o. of EEDT, significantly delayed the onset of convulsion $(p<0.01)$ and significantly reduced duration of convulsion $(p<0.05)$ in mice against INH induced convulsion. A dose of $800 \mathrm{mg} / \mathrm{kg}$ p.o. of EEDT dose significant delayed the onset of convulsion $(p<0.01)$ and significantly reduced the duration of action of convulsion induced by isoniazid. A dose of $800 \mathrm{mg} / \mathrm{kg}$ p.o. of ethanolic extract of D. triflorum showed $33.33 \%$ protection against INH induced convulsion in mice. The standard anticonvulsant drug, diazepam $10 \mathrm{mg} / \mathrm{kg}$

Table 1. Effect ethanolic extract of Desmodium triflorum on the Pentylenetetrazole-induced convulsion in mice.

\begin{tabular}{lcccc}
\hline \multicolumn{1}{c}{ Experimental group } & $\begin{array}{c}\text { Dose } \\
\mathrm{mg} / \mathrm{kg} \mathrm{b.w.}\end{array}$ & $\begin{array}{c}\text { Onset of clonic } \\
\text { convulsion (min.) }\end{array}$ & $\begin{array}{c}\text { Duration of } \\
\text { convulsion (min) }\end{array}$ & $\begin{array}{c}\text { Mortality/ } \\
\text { used (\%) }\end{array}$ \\
\hline Control (2\% tween 80$)$ & $2.0 \mathrm{ml} / \mathrm{kg}$ (p.o.) & $1.08 \pm 0.10$ & $4.79 \pm 1.03$ & $3 / 6(50 \%)$ \\
Standard (Diazepam) & $5.0 \mathrm{mg} / \mathrm{kg}$ (i.p.) & $0.00 \pm 0.00^{* * *}$ & $0.00 \pm 0.00^{* * *}$ & $0 / 6(0 \%)$ \\
EEDT & 400 (p.o.) & $3.68 \pm 0.42^{* *}$ & $2.16 \pm 0.45^{*}$ & $1 / 6(16.67 \%)$ \\
EEDT & 800 (p.o.) & $4.14 \pm 0.89^{* *}$ & $1.42 \pm 0.41^{* *}$ & $0 / 6(0 \%)$ \\
\hline
\end{tabular}

All values expressed as mean \pm SEM; $n=6$ mice in each group, by one-way ANOVA followed by Dunneet's Multiple Comparison Test (compared with control group) $* p<0.05, * * p<0.01$ and $* * * p<0.001$. 
i.p. totally abolished the effects of isoniazid induced convulsion in mice (Table 2).

Effect of extracts on MES-induced convulsion

The ethanolic extract of $D$. triflorum caused significant decrease in the duration of hind limb tonic extension (HLTE) induced by maximal electroshock. The EEDT group was compared with the control group. EEDT dose of $400 \mathrm{mg} / \mathrm{kg}$ p.o. reduced HLTE to $(p<0.05)$ and reduced the mortality to $16.66 \%$. EEDT dose of $800 \mathrm{mg} / \mathrm{kg}$ p.o. significantly reduced the duration of HLTE $(p<0.01)$ and no mortality was found against MES induced convulsion. Phenytoin $(25 \mathrm{mg} / \mathrm{kg}$ i.p.) significantly reduced the duration of MES-induced HLTE $(p<0.01)$ and completely prevented the various phases of convulsion induced by MES (Table 3 ).

\section{Effect on brain lipid peroxidation}

The effect of extract was showed significant inhibition of lipid peroxidation in mice brain tissue as compared to control group. The ethanolic extract of D. triflorum 400 and $800 \mathrm{mg} / \mathrm{kg}$ p.o. dose showed significant $(p<0.001)$ inhibition in malondialdehyde content compared to control group (Table 4).

Effects on reduced glutathion (GSH) level in mice brain tissue
The ethanolic extract of $D$. triflorum 400 and $800 \mathrm{mg} / \mathrm{kg}$ dose showed significant $(p<0.001)$ increases in brain GSH level compared to control (Table 5).

\section{Discussion}

The results of the present study demonstrate that ethanolic extract of Desmodium triflorum (L.) DC., Fabaceae, possessed anticonvulsant activity. EEDT dose of 400 and $800 \mathrm{mg} / \mathrm{kg}$ significant delayed the onset of convulsion, significantly reduced the duration of convulsion and no mortality was found of the mice against pentylenetetrazole-induced convulsion. The standard anti-epileptic drug diazepam (5 mg/ $\mathrm{kg}$ ) completely antagonized the seizures produced by pentylenetetrazole. PTZ may be exerting convulsant effect by inhibiting the activity of GABA at GABA-A receptors (Vasconcelos et al., 2007). GABA is a major inhibitory neurotransmitter in the brain, and the inhibition of its neurotransmission has been thought to be the underlying factor in epilepsy (Silambujanaki et al., 2010). The enhancement of the GABAergic neurotransmission is reported to antagonize seizures, while the inhibition of the neurotransmission promotes seizures (Amabeokua et al., 2007). The protection of mice against PTZ-induced seizures by the standard anticonvulsant drugs, phenobarbitone and diazepam is expected, since various authors have shown that they exert their anticonvulsant activities by enhancing

Table 2. Anticonvulsant effect ethanolic extract of Desmodium triflorum on the isoniazid-induced convulsion in mice.

\begin{tabular}{lcccc}
\hline \multicolumn{1}{c}{ Experimental group } & $\begin{array}{c}\text { Dose } \\
\mathrm{mg} / \mathrm{kg} \text { b.w. }\end{array}$ & $\begin{array}{c}\text { Onset of clonic } \\
\text { convulsion (min.) }\end{array}$ & $\begin{array}{c}\text { Duration of } \\
\text { convulsion (min) }\end{array}$ & $\%$ Protection \\
\hline Control (2\% tween 80$)$ & $2.0 \mathrm{ml} / \mathrm{kg}$ (p.o.) & $22.56 \pm 0.551$ & $5.65 \pm 0.375$ & $0.0 \%$ \\
Standard (Diazepam) & $10 \mathrm{mg} / \mathrm{mg}$ (i.p.) & $0.00 \pm 0.00^{* * *}$ & $0.00 \pm 0.00^{* * *}$ & $100 \%$ \\
EEDT & 400 (p.o.) & $35.72 \pm 1.956^{* * *}$ & $2.91 \pm 00.574^{*}$ & $0.0 \%$ \\
EEDT & 800 (p.o.) & $36.84 \pm 2.007^{* * *}$ & $2.86 \pm 0.696^{*}$ & $33.33 \%$ \\
\hline
\end{tabular}

All values expressed as mean \pm SEM; $n=6$ mice in each group, by one-way ANOVA followed by Dunneet's Multiple Comparison Test (compared with control group) $* p<0.05, * * p<0.01$ and $* * * p<0.001$.

Table 3. Anticonvulsant effect ethanolic extract of Desmodium triflorum on the MES-induced convulsion in mice.

\begin{tabular}{|c|c|c|c|c|c|c|}
\hline \multirow{2}{*}{$\begin{array}{l}\text { Experimental } \\
\text { group }\end{array}$} & \multirow{2}{*}{$\begin{array}{c}\text { Dose in } \mathrm{mg} / \mathrm{kg} \\
\text { b.w. }\end{array}$} & \multicolumn{4}{|c|}{ Time in seconds of various phase of convulsion } & \multirow{2}{*}{$\begin{array}{l}\text { Mortality/ } \\
\text { Used (\%) }\end{array}$} \\
\hline & & Flexion & $\begin{array}{c}\text { Extension } \\
\text { HLTE }\end{array}$ & Stupor & Recovery & \\
\hline $\begin{array}{l}\text { Control } \\
(2 \% \text { tween } 80)\end{array}$ & $2.0 \mathrm{~mL} / \mathrm{kg}$ (p.o.) & $17.33 \pm 2.24$ & $13.83 \pm 1.07$ & $142.5 \pm 7.50$ & $185.0 \pm 5.00$ & $4 / 6(66.66 \%)$ \\
\hline $\begin{array}{l}\text { Standard } \\
\text { (Phenytoin) }\end{array}$ & $25 \mathrm{mg} / \mathrm{kg}(i . p)$. & $9.00 \pm 1.36^{* *}$ & - & - & $11.50 \pm 1.17$ & $0 / 6(0.0 \%)$ \\
\hline EEDT & 400 (р.o.) & $12.67 \pm 1.60$ & $10.50 \pm 0.67 *$ & $60.17 \pm 20.57$ & $136.0 \pm 5.78$ & $1 / 6(16.66 \%)$ \\
\hline EEDT & 800 (p.o.) & $8.50 \pm 1.23 * *$ & $9.66 \pm 0.66 * *$ & $63.60 \pm 21.04 *$ & $118.3 \pm 9.38^{*}$ & $0 / 6(0.0 \%)$ \\
\hline
\end{tabular}

All values expressed as mean \pm SEM; $\mathrm{n}=6$ mice in each group, by one-way ANOVA followed by Dunneet's Multiple Comparison Test (compared with control group) $* p<0.05, * * p<0.01$ and $* * * p<0.001$. 
Table 4. Effect ethanolic extract of Desmodium triflorum on brain lipid peroxidation.

\begin{tabular}{lccc}
\hline \multicolumn{1}{c}{ Experimental group } & $\begin{array}{c}\text { Dose } \\
\mathrm{mg} / \mathrm{kg} \mathrm{b.w.}\end{array}$ & $\begin{array}{c}\text { Lipid peroxidation } \\
n \text { moles of MDA/mg of protein }\end{array}$ & $\begin{array}{c}\text { Decrease in MDA } \\
(\%)\end{array}$ \\
\hline Control $(2 \%$ tween 80$)+\mathrm{PTZ}$ & $2.0 \mathrm{~mL} / \mathrm{kg}$ (p.o.) & $0.558 \pm 0.019$ & 0.00 \\
EEDT + PTZ & 400 (p.o. $)$ & $0.288 \pm 0.012^{* * *}$ & 48.39 \\
EEDT + PTZ & 800 (p.o.) & $0.366 \pm 0.018^{* * *}$ & 34.75 \\
\hline
\end{tabular}

All values expressed as mean \pm SEM; $\mathrm{n}=6$ mice in each group, by one-way ANOVA followed by Dunneet's Multiple Comparison Test (compared with control group) $* p<0.05, * * p<0.01$, and $* * * p<0.001$

Table 6. Effect of ethanolic extract of Desmodium triflorum on glutathione (GSH) level in mice brain tissue.

\begin{tabular}{lccc}
\hline \multicolumn{1}{c}{ Experimental group } & $\begin{array}{c}\text { Dose } \\
\mathrm{mg} / \mathrm{kg} \mathrm{b.w.}\end{array}$ & $\begin{array}{c}\text { Glutathione } \\
\text { Micro moles } / \mathrm{mg} \text { of protein }\end{array}$ & Increase in GSH (\%) \\
\hline Control $(2 \%$ tween 80$)+\mathrm{PTZ}$ & $2.0 \mathrm{~mL} / \mathrm{kg}$ (p.o. $)$ & $9.95 \pm 0.16$ & 0.00 \\
EEDT $+\mathrm{PTZ}$ & 400 (p.o. $)$ & $14.06 \pm 0.25^{* * *}$ & 41.30 \\
EEDT $+\mathrm{PTZ}$ & 800 (p.o.) & $15.09 \pm 0.08^{* * *}$ & 51.65 \\
\hline
\end{tabular}

All values expressed as mean \pm SEM; $\mathrm{n}=6$ mice in each group, by one-way ANOVA followed by Dunneet's Multiple Comparison Test (compared with control group) $* p<0.05, * * p<0.01$ and $* * * p<0.001$.

GABA-mediated inhibition (Mahomed \& Ojewole, 2006).

The findings of the present study, therefore, tend to suggest that $D$. triflorum aqueous and ethanolic extracts have anticonvulsant activity might have inhibited and/or attenuated PTZ-induced seizures of the mice used by enhancing, or in some ways interfering with GABAergic neurotransmission. A dose of 400 and $800 \mathrm{mg} / \mathrm{kg}$ of EEDT significantly delayed the onset of convulsion and significantly reduced duration of action convulsion in mice against INH induced convulsion. A dose of EEDT $800 \mathrm{mg} / \mathrm{kg}$ showed $33.33 \%$ protection in mice against INH induced convulsion. The standard anticonvulsant drug, diazepam $10 \mathrm{mg} / \mathrm{kg}$ i.p. totally abolished the effects of INH induced convulsion in mice. It is well known that one of the factor responsible for isoniazid-induced convulsions is the decrease of GABA below a critical level in some neurons. Isoniazid was shown to lower the content of brain GABA to approximately the same extent in rats and mice (Pieri $\&$ Biry, 1985). Perhaps, the decrease in the amount of GABA stored presynaptically causes a reduction in the amount of GABA released by nerve impulses. Hence, the GABA receptors are regulated at the level of maximal sensitivity in order to maximize the action of GABA. Diazepam exhibits a marked protective effect against isoniazid-induced convulsions in mice (Corda et al., 1982). INH induced convulsion in mice significantly delayed the onset of seizure, reduced the duration of action and suggesting that D. triflorum DC extracts have a lesser protector effect in mice. The results suggested that AEDT and EEDT indicate weak anticonvulsant activity as compared to the PTZ and MES convulsion models.
The maximal electroshock induced convulsion in animals represents grandmal type of epilepsy. The tonic extensor phase is selectively abolished by the drugs effective in generalized tonic clonic seizure. The most outstanding action of phenytoin showed abolition of tonic extensor phase of MES seizure many drugs that increase the brain content of Gama amino butyric acid (GABA) have exhibited anticonvulsant activity against seizures induced by MES (Manigauha et al., 2009). There are numerous molecular mechanisms through which drugs can block seizure spread and or elevate seizure threshold. Indeed, attempts to correlate the anticonvulsant profiles of antiepileptic drugs with specific mechanisms of action reveal certain notable trends. MES induced tonic extension can be blocked by drugs such as phenytoin, carbamazepine, lamotrigine, felbamate and valproate that inhibit voltage-dependent $\mathrm{Na}^{+}$channels (Ambavadea et al., 2009).

The extract caused significant decrease in the duration of hind limb tonic extension (HLTE) induced by maximal electroshock. EEDT dose of 400 and 800 $\mathrm{mg} / \mathrm{kg}$ significantly reduced the duration of HLTE and reduced the mortality. The standard antiepileptic drug phenytoin $(25 \mathrm{mg} / \mathrm{kg}$ i.p. $)$ significantly reduced the duration of HLTE of MES-induced convulsion and completely abolished the various phases of convulsion. Reduction in the duration of tonic hind limb extension of MES induced convulsion indicated EEDT has anticonvulsant activity. Free radicals have been suggested to be the most likely candidates responsible for producing the neuronal changes mediating the behavioral deficits in neurodegenerative. Antioxidants are effective in rodent models of epilepsy, stroke and Alzheimer's disease (Golechha et al., 2010). Therefore 
the effect of EEDT on oxidative stress in PTZ induced convulsion was also evaluated. Mice pretreated with EEDT 400 and $800 \mathrm{mg} / \mathrm{kg}$ dose showed significant decrease in malondialdehyde content in mice brain compared with the control group. Glutathione is an endogenous antioxidant form within the free radicals and prevents the generation of hydroxyl radicals, the most toxic form of free radicals (Golechha et al., 2010). The decreased the level of reduced glutathione in control group mice seen in the present study indicates that there was an increased generation of free radicals and that the reduced glutathione was depleted during process of combating oxidative stress (Schulz et al., 2000). EEDT 400 and $800 \mathrm{mg} / \mathrm{kg}$ dose showed significant increases the GSH level in mice brain. The decreases in MDA and increase in the glutathione level in EEDT+PTZ mice indicates that EEDT exerted good antioxidant effect. Several studies also indicates that on medicinal plants antioxidant activities are due to the presence of polyphenols and flavonoids (Asuntha et al., 2010).

Phytochemical studies indicates the presence of phenolic compounds and flavonoids in D. triflorum. Phytochemical evaluation of $D$. triflorum revealed the presence of alkaloid, steroid, flavonoids, saponin, proteins and tannins in EEDT. Various phytochemicals have been reported to possess CNS activities. The anticonvulsant activity was attributed, alkaloids (Taesotikul et al., 1998), essential oils (Dallmeier \& Carlini, 1981), flavonoids (Asl et al., 2007), triterpenic steroids and triterpenoidal saponins are reported to possess anticonvulsant activity in some experimental seizure models such as MES and PTZ (Chauhan et al., 1988; Kasture et al., 2002). It is also found that many flavonoids could act as benzodiazepine- like molecules in the central nervous system and modulate GABA-generated chloride currents in animal models of anxiety, sedation and convulsion (Asl et al., 2007). In the present investigation, the anticonvulsant activity can be attributed to the presence of alkaloids, steroids, flavonoids, tannins and saponin in ethanolic extract of D. triflorum.

\section{Conclusion}

The ethanolic leaf extract of Desmodium triflorum (L.) DC., Asteraceae, demonstrated potential anticonvulsant properties and less toxicity in the experimental animals at the doses used. However, further studies still needed to be carried on exposure of the extract to humans, and its use in folk medicine for seizure control should be accompanied by regular assessment of level of consciousness and blood pressure.

\section{Acknowledgement}

The authors also like to express their thanks to Dr. Girish Gowda, previous HOD, Department of Pharmacology and Toxicology at St. John's Pharmacy College, Bangalore, India for designed the experimental aspects of this project and supervised the entire laboratory work.

\section{References}

Adinarayana D, Syamsundar KV 1982. Occurance of a rare diholosylflavone, 2-O-glucosylvitexin in Desmodium triflorum. Curr Sci 51: 936-937.

Amabeokua GJ, Green I, Kabatende J 2007. Anticonvulsant activity of Cotyledon orbiculata L. (Crassulaceae) leaf extract in mice. J Ethnopharmacol 112: 101-107.

Ambavadea SD, Mhetrea NA, Muthala AP, Bodhankar SL 2009. Pharmacological evaluation of anticonvulsant activity of root extracts of Saussurea Lappa in mice. Eur J Int Med 1: 131-137.

Asl MA, Rad SS, Zamansoltani F 2007. Anticonvulsant effects of aerial parts of Passiflora incarnata extract in mice: involvement of benzodiazepine and opioid receptors. BMC Complement Altern Med 7: 1-6.

Asuntha G, Prasannaraju Y, Prasad KV 2010. Effect of ethanol extract of Indigofera tinctoria Linn (Fabaceae) on lithium/pilocarpine-induced status epilepticus and oxidative stress in wistar rats. Trop J Pharm Res 9: 149-156.

Chauhan AK, Dobhal MP, Joshi BC 1988. A review of medicinal plants showing anticonvulsant activity. $J$ Ethnopharmacol 22: 111-123.

Corda MG, Costa E, Guidotti A 1982. Specific proconvulsant action of an imidazobenzodiazepine (RO 15-1788) on isoniazid convulsions. Neuropharmacol 21: 91-94.

Dallmeier K, Carlini EA 1981. Anesthetic, hypothermic, myorelaxant and anticonvulsant effects of synthetic eugenol derivatives and natural analogue. Pharmacol 22: 113-127.

Daya RW, Chandra JA, Tissa RCD, Rupika WK 2011. Antinociceptive activity of cold extract of Desmodium triflorum in rats. Int Res J Pharm 2: 120-123.

Ezekiel I, Mabrouk MA, Ayo JO, Goji AD, Okpanachi AO, Mohammed A, Tanko Y 2010. Study of the effect of hydro-ethanolic extract of Commiphora africana (stem-bark) on sleeping time and convulsion in mice. Asian J Med Sci 2: 85-88.

Ghosal R, Srivastava S, Banerjee PK, Dutta SK 1971. Alkaloids of Desmodium triflorum. Phytochemistry 10: 3313-3314.

Golechha M, Bhatia J, Arya DS 2010. Hydroalcoholic extract of Emblica officinalis Gaertn. afford protection against PTZ- induced sizure, oxidative stress and congnitive in rats. Ind J Exp Biol 48: 474-478. 
Hema B, Bhupendra S, Mohamed Saleem TS, Gauthaman K 2009. Anticonvulsant effect of Drosera burmannii Vahl. Int J Applied Res Nat Prod 2: 1-4.

Joy PP, Thomas J, Mathew S, Skaria BP 2001. Medicinal Plants Tropical Horticulture. Vol-2, Calcutta: Naya Prokashan.

Kasture VS, Kasture SB, Chopde CT 2002. Anticonvulsive activity of Butea monosperma flowers in laboratory animals. Pharmacol Biochem Behav 72: 965-972.

Kawshik KC, Achinto S, Sitesh CB, Joydeb KK 2005. Analgesic and anti-inflammatory activities of Desmodium triflorum DC. J Biol Sci 5: 581-583.

Khandelwal KR 1996. Practical pharmacognosy techniques and experiments. $3^{\text {rd }}$ ed. Pune: Nirali Prakashan.

Kirtikar KR, Basu BD 1980. Indian Medicinal Plants. $2^{\text {nd }}$ Ed., B. Singh and MP Singh Publishers, India. p. 760761.

Lai SC, Ho YL, Huang SC, Huang TH, Lai ZR, Wu CR, Lain KY, Chang YS 2010. Antioxidant and antiproliferative activities of Desmodium triflorum (L.) DC. Am J Chin Med 38: 329-342.

Mahomed IM, Ojewole JA 2006. Anticonvulsant activity of Harpagophytum procumbens DC. (Pedaliaceae) secondary root aqueous extract in mice. Brain Res Bull 69: 57-62.

Maiha BB, Magaji MG, Yaro AH, Hamza AH, Ahmed SJ, Magaj AR 2009. Anticonvulsant studies on cochlospermum tinctorium and Paullinia pinnata extracts in laboratory animals. Nig J Pharm Sci 8: 102-108.

Manigauha A, Patel S, Monga J, Ali H 2009. Evaluation of anticonvulsant activity of Pongamia pinnata Linn in experimental animals. Int J Pharm Tech Res 4: 11191121.

Mao SC, Li ZY, Li G 2007. Studies on antioxidation activity of three plants of Desmodium. Yunnan Daxue Xue Bao 29: 393-397.

Marjan NA, Zamansoltani F, Torabinejad B 2009. Antiepileptic effects of quinine in the pentylenetetrazole model of seizure. Seizure 8: 129-132.

Ohkawa H, Ohishi N, Yagi K 1979. Assay for lipid peroxides in animal tissues by thiobarbituric acid reaction. Anal Biochem 95: 351-358.

Pieri L, Biry P 1985. Isoniazid-induced convulsions in rats: effects of RO 15.1788 and $\beta$-CCE. Eur J Pharmacol 112: 355-362.

Prusti AB, Behera KK 2007. Ethno-medico botanical study of Sundargarh District, Orissa, India. Ethnobotanical Leaflets 11: 148-163.

Reddy DS 2005. Pharmacotherapy of catamenial epilepsy. Ind J Pharmacol 37: 288-293.
Samvatsar S 2004. Plant used for the treatment of different types of fever by Bhils and subtripes in India. Ind $J$ Traditional Knowledge 3: 96-100.

Schulz JB, Lindenau J, Seyfried J, Diechgans J 2009. Glutathione, oxidative stress and neurodegeneration. Eur J Biochem 267: 4904-4909.

Sedlak J, Lindsay RH 1968. Estimation of total protein bound and non protein bond sulphydryl group in tissue with Ellman's reagent. Anal Biochem 25: 192-197.

Silambujanaki P, Chitra V, Kumari S, Sankari M, Raju D, Chandra $\mathrm{CH}$ 2010. Anti-convulsant activity of methanolic extract of Butea monosperma leaves. RJPBCS 1: 431-435.

Swinyard EA, Brown WC, Goodman LS 1952. Comparative assays of antiepileptic drugs in mice and rats. $J$ Pharmacol Exp Ther 106: 319-330.

Taesotikul T, Panthong A, Kanjanapothi D, Verpoorte R, Scheffer JC 1998. Neuropharmacological activites of the crude alkaloidal fraction from stems of Tabernaemontana pandacaqui poir. J Ethnopharmacol 62: 229-234.

Trease GE, Evans MC 1983. Textbook of Pharmacognosy. London: Bailliare Tindall. 12: p. 193.

Tsai JC, Huang GJ, Chiu TH, Huang SS, Huang SC, Huang TH, Lai SC, Lee CY 2011. Antioxidant activities of phenolic components from various plants of Desmodium species. Afric J Pharm Pharmacol 5: 468-476.

Vasconcelos SM, Lima NM, Sales GT, Cunha GM, Aguiar LM, Silveira ER 2007. Anticonvulsant activity of hydroalcoholic extracts from Erythrina velutina and Erythrina mulungu. J Ethnopharmacol 110: 271-274.

Vogel H, Vogel G 2002. Wolfgang H (Ed.) Drug discovery and evaluation pharmacological assays (Springer). 2 (E), p. 424.

Vyawahare NS, Khandelwal AR, Batra VR, Nikam AP 2007. Herbal anticonvulsants. J Herb Med Toxicol 1: 9-14.

Wannang NN, Anuka JA, Kwanashie HO, Gyang SS, Auta A 2008. Anti-seizure activity of the aqueous leaf extract of Solanum nigrum L. (Solanaceae) in experimental animal. Afr Health Sci 8: 74-79.

Yoganarasimhan SN 1996. Medicinal plants of India. Vol-1, Karnataka: Interline Publishers.

\section{*Correspondence}

Girish Gowda

Department of Pharmacognosy and Phytochemistry, St. John's Pharmacy College \#6, II Main, R.P.C Lay out, Bangalore, Karnataka, India sjpc@stjohns.edu.in Tel.: +919632542846 